\title{
The effects of acute blood loss on electrocardiogram in male and female Swiss albino mice
}

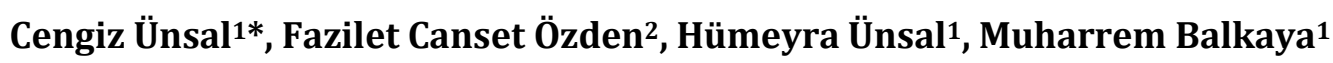

\section{Research Article}

Volume: 2, Issue: 3 December 2018

Pages: 66-71

\section{Article History}

Received: 13.08 .2018

Accepted: 28.09.2018

Available online:

29.09.2018
1. Department of Physiology Faculty of Veterinary Medicine, Adnan Menderes University, 09016, Işıklı-Aydın, Turkey. 2. Bodrum-Muğla, Turkey.

\begin{abstract}
The aim of the present study is to investigate the possible effects of acute blood loss ( $1 \%$ of body weight) on electrocardiogram (ECG) in male and female Swiss albino mice. Anesthesia was maintained with the ketamine-xylazine combination. The tail was cut using a scalpel blade and blood at a ratio of $1 \%$ body weight was collected in capillary tubes. ECG recording was done by using the standard lead II. P and T waves, intervals of PQ, QT, and RR, and QRS complex were measured after all ECG was recorded. The amplitude of $P$ and QRS waves were significantly higher in males than that of females $(P<0.005, P<0.05$ respectively). $P R$ intervals were also longer in male mice than those of females $(P<0,001)$. Neither blood removal nor anesthesia affected the amplitude of the QRS complex in any gender. The duration of the QRS complex was longer in males than females in both groups $(P<0,01)$. Blood removal led to a reduction in the duration of the QRS complex in male mice $(P<0.01)$. Anesthesia caused the prolongation of the QT and QTc in all groups $(\mathrm{P}<0,001, \mathrm{P}<0,05$ respectively). Females had longer $\mathrm{QT}$ interval compared to male groups $(P<0,05)$ and blood removal caused prolongation of the QT period in females $(P<0,05)$. An acute blood loss of $1 \%$ of body weight in male mice led to a reduction in heart rate, whereas prolongation of the QT interval in female mice. It was concluded that gender is an important factor in terms of blood-loss associated ECG alterations.
\end{abstract}

Keywords: ECG, ketamine, xylazine, blood loss, mouse, gender

DOI: $10.30704 / \mathrm{http}-w w w-j i v s-n e t .453151$

To cite this article: Unsal, C., Canset Ozden, F., Unsal, H., Balkaya, M.(2018). The The effects of acute blood loss on electrocardiogram in male and female Swiss albino mice. 2(3), 66-71. Abbreviated Title: J Ist Vet Sci

\section{Introduction}

Blood collection is required for performing hematological, biochemical, pharmacologic, and toxicological analyses (Raabe et al., 2011). The blood collection method depends on type of the analyses and duration and frequency of sampling (Gargiulo et al., 2012). Blood sampling procedures affect the data collected from a study conducted in smaller laboratory animals. The amount and frequency of blood collected have adverse effect on animals such as immunosuppression, reduction in blood pressure, anemia, hemorrhagic shock, or mortality (Xu et al., 2007). A typical rule is to not exceed removal of $10 \%$

*Corresponding Author: Cengiz Ünsal

E-mail: cunsal@adu.edu.tr of total blood volume (roughly $1 \%$ of body weight or 8 $\mathrm{mL} / \mathrm{kg}$ ) for every 2-week period (Gargiulo et al., 2012). The minor blood losses may be asymptomatic in animals. Loss of about $10 \%$ or less of the total blood volume causes baroreceptor-initiated reflexes which leads further release of adrenergics from the adrenal medulla and sympathetic nerve endings, which causes an increase in heart rate and construction in veins, venous reservoirs, and arteriolar beds in muscle and skin (McGuill \& Rowan, 1989). The cardiac functions determined by electrocardiogram under anesthesia are found to be usually depressed compared with the cardiac functions found in the conscious state. The ideal drug must be safe and simple to use and induce

Journal homepage: www.jivs.net http://dergipark.gov.tr/http-www-jivs-net 
Unsal, C. et al. 2018 / Journal of Istanbul Veterinary Sciences. Volume 2, Issue 3, pp: 66-71

reproducible sedation and immobility without causing any changes in cardiac function and heart rate (Lairez et al., 2013). The combination of ketamine and xylazine is popular for inducing anesthesia in many species including mice. This combination has some advantages such as to provide single injection, easier animal handling, well-controlled anesthetic depth and duration, and fewer side-effects after being awoken (Xu et al., 2007). However, previous studies have shown that lowered heart rate (HR), depressed contractile function, loss of animals with overt heart disease and functional instability may occur (Roth et al., 2002; Tan et al., 2003).

This study aimed to determine the effects of maximum amount of blood that can be taken at once without causing any adverse effects on the ECG in male and female mice.

\section{Materials and methods}

\section{Animals}

The study was approved by Adnan Menderes University Local Ethics Committee for Animal Experiments (Protocol number: 2010-60). A total of 28 Swiss Albino mice of both sexes, six months of age, were randomly divided into four groups of equal size: males and females from which blood were taken and control group of males and females. Mice were housed in the same room with a 12:12 h. light/dark cycle at a $22 \pm 1{ }^{\circ} \mathrm{C}$ temperature and relative humidity of $40-50 \%$. The mice were then allowed ad libitum access to water and standard laboratory rodent chow. Anesthesia was maintained by intraperitoneally injected ketamine-xylazine combination (ketamine (80 $\mathrm{mg} / \mathrm{kg}$, Alfamine, xylazine; $10 \mathrm{mg} / \mathrm{kg}$, Alfazyne, EGE$\mathrm{VET}^{\oplus}$, Turkey). The induction of anesthesia was controlled by the loss of righting reflex. Depth of anesthesia was determined by checking the pedal withdrawal reflex. Mice were then laid down on their back immediately after having achieved anesthesia and placed on heating pads to maintain their body temperature at $37^{\circ} \mathrm{C}$. The tail $(1 \mathrm{~cm}$ from distal) was quickly cut by using a scalpel. Blood was collected at a ratio of $1 \%$ of body weight in capillary tubes.

\section{ECG Recording}

After the blood collection, bleeding was stopped by applying pressure to the bleeding area. ECG recordings were done using MP30 data acquisition system (BIOPAC ${ }^{\circledR}$, USA) at a rate of $2 \mathrm{kHz}$ and the data were collected in a personal computer until being analyzed. The standard lead II was used to record ECG. Bipolar surface electrodes (EL254S, EL254 BIOPAC $^{\circledR}$, USA) were placed on the right forelimb and on each hindlimb. The electrodes were then gently connected to the MP30 data acquisition system by using the ECG gel. ECG recording continued throughout the anesthesia. Recordings were analyzed by using BIOPAC BSL 3.7.2 program, a software for MP30 data acquisition system. All ECG frontal axis ( $P$ and $Q R S$ ) and time intervals (PR, QRS, QT and RR) were calculated from each mouse in lead II. The QT intervals were also rate-corrected with adapted Bazett's formula (Mitchell et al., 1998).

\section{Statistical Analyses}

Data were presented as mean and standard error of the mean. Shapiro-Wilk and Levene tests were used for normal distribution of the data and homogeneity of variance. Data were analyzed by using SPSS 19.0 $\left(\mathrm{IBM}^{\circledR}, \mathrm{USA}\right)$ software package. Repeated measures performed by three-way ANOVA were conducted to evaluate the effects of anesthesia, gender and blood loss. Post hoc multiple comparisons were done when any intervention are significant. The significance level was set at $p<0.05$.

\section{Results}

Results are shown in Table 1. It was found that the anesthesia led to a reduction in heart rate $(P<0.01)$, which was more distinct in males compared to females $(P<0.05)$. Furthermore, blood removal affected males more than females $(P<0.001)$ in the first 10 minutes after onset of the blood collection. $P$ wave amplitudes were lower in female mice than those of males for both study and control groups $(P<0.01)$. The durations of $P$ wave were not different in all groups. PR interval did not change by time and blood loss did not have any gender effect on PR interval. However, females had shorter PR interval than males in both the group from whose members blood were collected and in the control group $(P<0.01)$. The amplitude of the $Q R S$ complex was higher in males than females $(P<0.05)$. Neither blood removal nor anesthesia affected the amplitude of the QRS complex in any gender. The duration of the QRS complex was longer in males than females in both groups $(P<0.001)$. Anesthesia affected the duration of the QRS complex in male and female mice $(P<0.001)$. Blood removal led to a reduction in the duration of the QRS complex in male mice $(P<0.001)$. Anesthesia caused the prolongation of the QT and QTc in all groups ( $p<0.001, P<0.05$, respectively). Females had longer QT interval compared to male groups $(P<0.05)$ and blood removal caused prolongation of the QT period in females $(P<0.05)$. Any clear and separate $T$ wave could be reliably distinguished from almost any ECG recordings. 
Table 1. ECG parameters in mice

\begin{tabular}{|c|c|c|c|c|c|}
\hline \multirow[b]{3}{*}{ Variables } & \multirow{3}{*}{$\begin{array}{l}\text { Time } \\
(\min )\end{array}$} & \multicolumn{4}{|c|}{ Groups } \\
\hline & & \multicolumn{2}{|c|}{ Experiment } & \multicolumn{2}{|c|}{ Control } \\
\hline & & Female & Male & Female & Male \\
\hline \multirow{5}{*}{$\begin{array}{l}\text { P Wave Amplitude } \\
\qquad(\mu \mathrm{V})\end{array}$} & 0 & $4.05 \pm 0,61$ & $6.76 \pm 0.57$ & $4.59 \pm 1.06^{b}$ & $10.78 \pm 1.99^{b}$ \\
\hline & 10 & $2.67 \pm 0.19$ & $7.22 \pm 0.70$ & $4.33 \pm 0.67^{b}$ & $9.67 \pm 1.59^{b}$ \\
\hline & 20 & $4.59 \pm 1.36$ & $5.98 \pm 0.81$ & $4.16 \pm 0.50^{b}$ & $9.62 \pm 1.48^{b}$ \\
\hline & 30 & $2.34 \pm 0.32^{\mathrm{a}}$ & $8.15 \pm 0.76^{a}$ & $4.61 \pm 0.67^{b}$ & $8.81 \pm 1.07^{b}$ \\
\hline & 40 & $2.25 \pm 0.39^{\mathrm{a}}$ & $7.91 \pm 0.90^{\mathrm{a}}$ & $4.18 \pm 0.68$ & $8.14 \pm 1.12$ \\
\hline \multirow{5}{*}{$\begin{array}{l}\text { P Wave Duration } \\
\text { (msec) }\end{array}$} & 0 & $34.53 \pm 1.10$ & $39.64 \pm 1.45$ & $35.19 \pm 0.96$ & $39.83 \pm 2.35$ \\
\hline & 10 & $36.29 \pm 0.60$ & $39.56 \pm 1.43$ & $42.97 \pm 1.12$ & $41.58 \pm 1.21$ \\
\hline & 20 & $42.62 \pm 0.99$ & $39.07 \pm 1.50$ & $35.14 \pm 2.01$ & $42.17 \pm 2.09$ \\
\hline & 30 & $38.50 \pm 3.58$ & $37.36 \pm 1.82$ & $37.10 \pm 3.08$ & $43.36 \pm 3.12$ \\
\hline & 40 & $39.96 \pm 2.59$ & $40.58 \pm 1.82$ & $40.14 \pm 2.05$ & $38.07 \pm 2.25$ \\
\hline \multirow{5}{*}{$\begin{array}{c}\text { QRS } \\
\text { Amplitude }\end{array}$} & 0 & $47.04 \pm 3.23^{a}$ & $67.91 \pm 6.20^{\mathrm{a}}$ & $40.02 \pm 3.29^{b}$ & $79.55 \pm 7.78^{b}$ \\
\hline & 10 & $45.81 \pm 3.40^{\mathrm{a}}$ & $68.64 \pm 4.96^{\mathrm{a}}$ & $39.47 \pm 2.55^{b}$ & $82.68 \pm 8.27^{b}$ \\
\hline & 20 & $47.18 \pm 2.79^{a}$ & $68.90 \pm 5.20^{a}$ & $40.79 \pm 3.20^{b}$ & $84.60 \pm 8.31^{b}$ \\
\hline & 30 & $44.00 \pm 3.25^{\mathrm{a}}$ & $79.10 \pm 2.60^{a}$ & $39.17 \pm 3.91^{b}$ & $86.83 \pm 8.86^{b}$ \\
\hline & 40 & $43.53 \pm 3.32^{\mathrm{a}}$ & $67.64 \pm 5.60^{\mathrm{a}}$ & $40.51 \pm 3.86^{b}$ & $89.86 \pm 8.25^{b}$ \\
\hline \multirow{5}{*}{$\begin{array}{l}\text { QRS Duration } \\
\text { (msec) }\end{array}$} & 0 & $43.43 \pm 1.19$ & $47.21 \pm 2.26^{c}$ & $43.83 \pm 0.78^{b}$ & $61.02 \pm 3.39^{b c}$ \\
\hline & 10 & $41.57 \pm 1.86$ & $51.96 \pm 4.87^{c}$ & $45.67 \pm 2.63^{b}$ & $55.04 \pm 1.44^{b c}$ \\
\hline & 20 & $41.79 \pm 1.29^{a}$ & $58.80 \pm 4.18^{\mathrm{ac}}$ & $43.83 \pm 3.53^{b}$ & $68.89 \pm 3.65^{b c}$ \\
\hline & 30 & $44.71 \pm 2.10^{\mathrm{a}}$ & $63.86 \pm 2.91^{\mathrm{ac}}$ & $46.15 \pm 2.90^{b}$ & $72.60 \pm 2.42^{b c}$ \\
\hline & 40 & $44.29 \pm 1.15$ & $54.12 \pm 1.71^{\mathrm{c}}$ & $45.10 \pm 4.40^{b}$ & $79.78 \pm 3.88^{b c}$ \\
\hline \multirow{5}{*}{$\begin{array}{l}\text { Heart Rate } \\
\text { (BPM) }\end{array}$} & 0 & $266.1 \pm 16.3$ & $189.1 \pm 21.4^{b}$ & $288.2 \pm 25.7$ & $292.6 \pm 22.3^{b}$ \\
\hline & 10 & $236.6 \pm 12.4^{a}$ & $126.5 \pm 8.3^{\mathrm{ab}}$ & $211.3 \pm 6.7$ & $198.1 \pm 12.5^{b}$ \\
\hline & 20 & $221.9 \pm 10.8^{a}$ & $108.3 \pm 7.5^{\mathrm{ab}}$ & $229.0 \pm 8.1^{c}$ & $154.6 \pm 10.4^{b c}$ \\
\hline & 30 & $210.9 \pm 11.0^{\mathrm{a}}$ & $133.3 \pm 21.1^{\mathrm{a}}$ & $214.17 \pm 6.4^{c}$ & $125.7 \pm 8.9^{c}$ \\
\hline & 40 & $215.3 \pm 10.6^{a}$ & $128.8 \pm 22.8^{\mathrm{a}}$ & $239.67 \pm 12.0^{c}$ & $111.7 \pm 7.2^{c}$ \\
\hline \multirow{5}{*}{$\begin{array}{l}\text { PR Interval } \\
\text { (msec) }\end{array}$} & 0 & $35.03 \pm 0.99^{a}$ & $46.83 \pm 1.37^{\mathrm{a}}$ & $37.14 \pm 0.91^{b}$ & $45.50 \pm 1.50^{b}$ \\
\hline & 10 & $34.90 \pm 0.93^{\mathrm{a}}$ & $51.50 \pm 2.36^{a}$ & $43.37 \pm 1.67$ & $44.59 \pm 1.81$ \\
\hline & 20 & $46.05 \pm 2.30$ & $45.42 \pm 1.26$ & $37.39 \pm 2.13^{b}$ & $50.17 \pm 2.71^{b}$ \\
\hline & 30 & $38.58 \pm 3.62^{\mathrm{a}}$ & $45.42 \pm 2.47^{\mathrm{a}}$ & $39.32 \pm 1.43^{b}$ & $53.33 \pm 2.82^{b}$ \\
\hline & 40 & $35.42 \pm 1.89^{a}$ & $48.50 \pm 2.53^{a}$ & $40.82 \pm 2.01^{b}$ & $52.42 \pm 2.71^{b}$ \\
\hline \multirow{5}{*}{$\begin{array}{l}\text { QT Interval } \\
\text { (msec) }\end{array}$} & 0 & $146.71 \pm 5.66^{\mathrm{ab}}$ & $85.33 \pm 4.53^{b}$ & $102.75 \pm 4.81^{\mathrm{ac}}$ & $78.97 \pm 4.82^{c}$ \\
\hline & 10 & $160.60 \pm 2.86^{\mathrm{ab}}$ & $82.00 \pm 3.07^{b}$ & $102.02 \pm 2.52^{\mathrm{ac}}$ & $77.33 \pm 1.60^{c}$ \\
\hline & 20 & $157.92 \pm 2.85^{\mathrm{ab}}$ & $94.57 \pm 5.27^{b}$ & $97.32 \pm 3.20^{\mathrm{a}}$ & $93.66 \pm 3.80$ \\
\hline & 30 & $165.66 \pm 4.73^{\mathrm{ab}}$ & $106.17 \pm 6.71^{b}$ & $100.25 \pm 4.33^{\mathrm{a}}$ & $99.04 \pm 3.42$ \\
\hline & 40 & $165.43 \pm 4.73^{\mathrm{ab}}$ & $104.93 \pm 1.77^{b}$ & $115.42 \pm 2.84^{\mathrm{ac}}$ & $98.94 \pm 2.88^{c}$ \\
\hline \multirow{5}{*}{$\begin{array}{l}\text { QTc Interval } \\
\text { (msec) }\end{array}$} & 0 & $97.01 \pm 2.81$ & $48.04 \pm 5.15$ & $71.23 \pm 6.27$ & $53.38 \pm 3.54$ \\
\hline & 10 & $99.15 \pm 1.93$ & $37.31 \pm 0.82$ & $61.08 \pm 1.21$ & $44.35 \pm 1.77$ \\
\hline & 20 & $95.83 \pm 2.82$ & $39.95 \pm 2.46$ & $60.24 \pm 3.17$ & $47.03 \pm 0.83$ \\
\hline & 30 & $97.73 \pm 2.46$ & $49.27 \pm 4.94$ & $59.80 \pm 2.42$ & $45.02 \pm 1.67$ \\
\hline & 40 & $98.52 \pm 1.06$ & $50.59 \pm 4.05$ & $72.88 \pm 2.83$ & $41.39 \pm 0.97$ \\
\hline
\end{tabular}

Within rows, means followed by the same letter are significantly different $(P<0.05)$ 


\section{Discussion}

Clinical and experimental studies have shown that gender is an important factor in cardiac electrophysiology in human and various animal species (Cheng, 2006). The differences in the ECG between men and women are that the P-wave and P$\mathrm{R}$ intervals are slightly longer in men than in women. Women have higher resting heart rate than men do, but a longer rate-corrected QT (QTC) interval, indicating that there is intrinsic sex-related differences in the electrophysiological properties of the myocardium (James et al., 2007).

At the beginning of the adolescence, the resting heart rate is faster in males than females (Moss, 2010). However, some previous animal studies speculated that cardiac electrophysiological properties between male and female mice were generally similar (Appleton et al., 2004; Berul et al., 1998). We observed that the combination of ketamine -xylazine decreased the heart rate throughout the anesthesia in all groups. Different types of sedation and different doses of ketamine-xylazine combination cause variation on heart rates (Appleton et al., 2004; Erhardt et al., 1984; Mitchell et al., 1998; Roth et al., 2002; Stypmann, 2007). Xylazine (5-10 mg/kg ip) induces sedation, but it seems to have little analgesic effect when used alone in mice. The combination of ketamine $(80-100 \mathrm{mg} / \mathrm{kg}$ ip) and xylazine $(10 \mathrm{mg} / \mathrm{kg}$ ip) gives about 20-30 minutes of anesthesia (Flecknell, 2009). However, respiratory depression, reduction in heart rate and blood pressure might also be seen (Erhardt et al., 1984). Ketamine exerts negative inotropic effects on the heart (Rusy et al., 1990) and inhibits both $\mathrm{Na}+$ and $\mathrm{Ca}++$ channels (Hara et al., 1998). In our study, the heart rate was found lower compared to the studies mentioned above. This difference in the heart rate may depend on age, size and strain of the mice studied, and inter-strain differences in response to anesthesia and the anesthetic regimens used (Gargiulo et al., 2012). The male mice from which blood was withdrawn had a low heart rate in the first 20 minutes of the experiment. There is an initial arterial baroreceptor-mediated phase in acute blood loss (phase I, until 25-35\% of blood volume is lost) characterized by a sympathoexcitatory response, resulting in maintenance of arterial blood pressure at baseline levels (Ryan et al., 2012; Schadt \& Ludbrook, 1991). The hypotensive hemorrhage induces a short-lasting sympathetic excitation followed by a powerful sympathetic inhibition and bradycardia within 5-10 minutes in rats (Skoog et al., 1985). Slowing down of the heart rate when action potential is prolonged may lead to an increase in early afterdepolarization, which may trigger polymorphic ventricular tachyarrhythmias such as torsade de pointes (Jeron et al., 2000).

The amplitude and interval of $P$ wave did not change during anesthesia and after blood withdrawal in the present study. We found that $P$ wave duration of our mice was not similar to other studies conducted with the other mouse strains (Appleton et al., 2004). In human, duration of the $\mathrm{P}$ wave has been reported to be slightly longer in men than that of women and this gender difference may be related to smaller atrial size in women compared to men (Dhala et al., 2002).

In human, the QT and the QTc interval are longer and the amplitude and duration of QRS are larger in men than that of women at the beginning of the adolescence (Moss, 2010). The amplitude and duration of QRS are higher and longer, respectively, in male mice than those of females in present study. In human, the androgens and androgen-mediated increase in cardiac mass and left ventricular wall thickness cause larger QRS amplitude in males than females (Sachin Khane \& Surdi, 2012). Blood withdrawal resulted in a reduction in the duration of the QRS complex in male mice. The cardiac $\mathrm{K}+$ currents/channels which can be regulated by male sex hormones and androgens are the two major regulatory factors in cardiac repolarization in mice (Brouillette et al., 2003; Brouillette et al., 2005). In our analysis, females' QT intervals were longer than those of males. Mitchell et al. (1998) reported that ketamine anesthesia prolonged the QT interval in mice and this effect was for both gender as the QT and QTc interval were not different between the male and female mice. Speerschneider \& Thomsen (2013) suggest the QTc interval is not useful in mice because the cardiac repolarization in the anaesthetized mouse is independent of paced heart rate and thus, this might cause overcorrection of the QT interval.

A well-defined T wave separated from the QRS is absent in murine (Danik et al., 2002). Although some important differences have been described, morphologically, $\mathrm{M}$ cells look similar to epicardial and endocardial cells, but functionally, they are more similar to Purkinje cells (Yan et al., 1998). M cells seem like absent in mouse, which makes the magnitude of the transmural repolarization gradient significantly smaller, eventually leading to the absence of a T wave in the murine ECG (Liu et al., 2004). 
In conclusion, as reported in previous studies, there is a gender difference for electrocardiographic parameters in anesthetized mice. In addition, anesthesia is an important intervention factor on electrocardiogram. Therefore, electrocardiography should be performed both during and after onset of anesthesia. The effects of an acute blood loss of $1 \%$ of body weight on electrocardiogram vary depending on gender. It should be considered that blood sampling within the acceptable upper limits may have an effect on electrocardiographic variables and gender differences might also play another distinct role on the electrocardiographic variables.

\section{Acknowledgment}

We thank to Amanda Chilaka, technical assistant in Whitehead Institute, for language editing.

\section{References}

Appleton, G. O., Li, Y., Taffet, G. E., Hartley, C. J., Michael, L. H., Entman, M. L., Roberts, R. \& Khoury, D. S. (2004). Determinants of cardiac electrophysiological properties in mice. Journal of Interventional Cardiac Electrophysiology, 11(1), 5-14.

Berul, C. I., Christe, M. E., Aronovitz, M. J., Maguire, C. T., Seidman, C. E., Seidman, J. G. \& Mendelsohn, M. E. (1998). Familial hypertrophic cardiomyopathy mice display gender differences in electrophysiological abnormalities. Journal of Interventional Cardiac Electrophysiology, 2(1), 7-14.

Brouillette, J., Rivard, K., Lizotte, E. \& Fiset, C. (2005). Sex and strain differences in adult mouse cardiac repolarization: importance of androgens. Cardiovascular Rearch, 65(1), 148-157.

Brouillette, J., Trepanier-Boulay, V. \& Fiset, C. (2003). Effect of androgen deficiency on mouse ventricular repolarization. The Journal of Physiology, 546(Pt 2), 403413.

Cheng, J. (2006). Evidences of the gender-related differences in cardiac repolarization and the underlying mechanisms in different animal species and human. Fundamentals \& Clinical Pharmacology, 20(1), 1-8.

Danik, S., Cabo, C., Chiello, C., Kang, S., Wit, A. L. \& Coromilas, J. (2002). Correlation of repolarization of ventricular monophasic action potential with ECG in the murine heart. American Journal of Physiolology: Heart and Circulatory Physiology, 283(1), H372-381.

Dhala, A., Underwood, D., Leman, R., Madu, E., Baugh, D., Ozawa, Y., Kasamaki, Y., Xue, Q., Reddy, S. \& Multicenter, P.-R. S. (2002). Signal-averaged P-wave analysis of normal controls and patients with paroxysmal atrial fibrillation: a study in gender differences, age dependence, and reproducibility. Clinical Cardiology, 25(11), 525-531.

Erhardt, W., Hebestedt, A., Aschenbrenner, G., Pichotka, B.
\& Blumel, G. (1984). A Comparative-study with various anesthetics in mice (pentobarbital, ketamine-xylazine, carfentanyl-etomidate). Research in Experimental Medicine, 184(3), 159-169.

Flecknell, P. (2009). Laboratory Animal Anaesthesia. San Francisco, USA, Elsevier Science.

Gargiulo, S., Greco, A., Gramanzini, M., Esposito, S., Affuso, A., Brunetti, A. \& Vesce, G. (2012). Mice anesthesia, analgesia, and care, Part I: anesthetic considerations in preclinical research. ILAR Journal, 53(1), E55-69.

Gargiulo, S., Greco, A., Gramanzini, M., Esposito, S., Affuso, A., Brunetti, A. \& Vesce, G. (2012). Mice anesthesia, analgesia, and care, Part II: anesthetic considerations in preclinical imaging studies. ILAR Journal, 53(1), E70-81.

Hara, Y., Chugun, A., Nakaya, H. \& Kondo, H. (1998). Tonic block of the sodium and calcium currents by ketamine in isolated guinea pig ventricular myocytes. The Journal of Veterinary Medical Science, 60(4), 479-483.

James, A. F., Choisy, S. C. \& Hancox, J. C. (2007). Recent advances in understanding sex differences in cardiac repolarization. Progress in Biophysics and Biophysical Chemistry, 94(3), 265-319.

Jeron, A., Mitchell, G. F., Zhou, J., Murata, M., London, B., Buckett, P., Wiviott, S. D. \& Koren, G. (2000). Inducible polymorphic ventricular tachyarrhythmias in a transgenic mouse model with a long Q-T phenotype. American Journal of Physiolology: Heart and Circulatory Physiology, 278(6), H1891-1898.

Lairez, O., Lonjaret, L., Ruiz, S., Marchal, P., Franchitto, N., Calise, D., Fourcade, O., Mialet-Perez, J., Parini, A. \& Minville, V. (2013). Anesthetic regimen for cardiac function evaluation by echocardiography in mice: comparison between ketamine, etomidate and isoflurane versus conscious state. Laboratory Animal, 47(4), 284290.

Liu, G., Iden, J. B., Kovithavongs, K., Gulamhusein, R., Duff, H. J. \& Kavanagh, K. M. (2004). In vivo temporal and spatial distribution of depolarization and repolarization and the illusive murine T wave. The Journal of Physiology, 555(Pt 1), 267-279.

McGuill, M. V. \& Rowan, A. N. (1989). Biological effects of blood loss: Implications for sampling volumes and techniques. ILAR Journal, 31(4), 5-20.

Mitchell, G. F., Jeron, A. \& Koren, G. (1998). Measurement of heart rate and $\mathrm{Q}-\mathrm{T}$ interval in the conscious mouse. The American Journal of Physiology, 274(3 Pt 2), H747-751.

Moss, A. J. (2010). Gender differences in ECG parameters and their clinical implications. Annals of Noninvasive Electrocardiology, 15(1), 1-2.

Raabe, B. M., Artwohl, J. E., Purcell, J. E., Lovaglio, J. \& Fortman, J. D. (2011). Effects of weekly blood collection in C57BL/6 mice. Journal of the American Association for Laboratory Animal Science, 50(5), 680-685. 
Roth, D. M., Swaney, J. S., Dalton, N. D., Gilpin, E. A. \& Ross, Skoog, P., Mansson, J. \& Thoren, P. (1985). Changes in renal J., Jr. (2002). Impact of anesthesia on cardiac function during echocardiography in mice. American Journal of sympathetic outflow during hypotensive haemorrhage in rats. Acta Physiologica Scandinavica, 125(4), 655-660.

Physiolology: Heart and Circulatory Physiology, 282(6), Speerschneider, T. \& Thomsen, M. B. (2013). Physiology and H2134-2140.

Rusy, B. F., Amuzu, J. K., Bosscher, H. A., Redon, D. \& Komai, H. (1990). Negative inotropic effect of ketamine in rabbit ventricular muscle. Anesthesia and Analgesia, 71(3), 275278. analysis of the electrocardiographic T wave in mice. Acta Physiologica (Oxford), 209(4), 262-271.

Ryan, K. L., Rickards, C. A., Hinojosa-Laborde, C., Cooke, W. H. \& Convertino, V. A. (2012). Sympathetic responses to central hypovolemia: new insights from microneurographic recordings. Frontiers in Physiology, 3, 110.

Stypmann, J. (2007). Doppler ultrasound in mice. Echocardiography, 24(1), 97-112.

Tan, T. P., Gao, X. M., Krawczyszyn, M., Feng, X., Kiriazis, H., Dart, A. M. \& Du, X. J. (2003). Assessment of cardiac function by echocardiography in conscious and anesthetized mice: importance of the autonomic nervous system and disease state. Journal of Cardiovascular Pharmacology, 42(2), 182-190.

Sachin Khane, R. \& Surdi, A. D. (2012). Gender differences in Xu, Q., Ming, Z., Dart, A. M. \& Du, X. J. (2007). Optimizing the prevalence of electrocardiogram abnormalities in the elderly: a population survey in India. Iranian Journal of Medical Sciences, 37(2), 92-99.

dosage of ketamine and xylazine in murine echocardiography. Clinical and Experimental Pharmacology \& Physiology, 34(5-6), 499-507.

Schadt, J. C. \& Ludbrook, J. (1991). Hemodynamic and Yan, G. X., Shimizu, W. \& Antzelevitch, C. (1998) neurohumoral responses to acute hypovolemia in conscious mammals. American Journal of Physiology, 260 (2 Pt 2), H305-318. Characteristics and distribution of $M$ cells in arterially perfused canine left ventricular wedge preparations. Circulation, 98(18), 1921-1927. 